\title{
PSYCHE
}

VOL. XLVII

MARCH, 1940

No. 1

\section{OBSERVATIONS IN CUBA ON INSECT MIMICRY AND WARNING COLORATION.}

\author{
By C. T. PARSONS
}

Biological Laboratories, Harvard University

The following cage experiments on mimicry and warning coloration were conducted at the instance of an article by P. J. Darlington, Jr. ${ }^{1}$ This paper is intended to supplement rather than to repeat Dr. Darlington's extensive remarks on the environment in which the mimicry occurs. These few observations, incidental to other work, are fragmentary. Yet opportunity to gather such information is so rare that the following notes are thought worthy of record.

The writer is greatly indebted to Dr. Thomas Barbour who made possible the stay in Cuba under a Harvard Fellowship of the Atkins Institution at Soledad, near Cienfuegos. Professor C. T. Brues very kindly took charge of the special photography involved. Also to Dr. Darlington and Doris $\mathrm{H}$. Blake for advice and assistance in identifying the insects the writer is under obligation.

Dr. Darlington described an example of mimicry, occurring at Soledad, in which a lizard, Anolis sagrei (D. \& B.) is the chief predator. In his experiments Darlington observed that the Anolis refused beetles of several different families. Apparently these were mimics of two very similar species of inedible Lycid beetles, Thonalmus suavis (J.-D.) and T. aulicus (J.-D.).

An examination of the plate of photographs should elucidate the descriptions that follow.

\footnotetext{
${ }^{1}$ P. J. Darlington, Jr., 1938, Experiments on mimicry in Cuba with suggestions for future study. Trans. R. ent. Soc. London, 87: 681-695.
} 
EXAMPles OF Mimicry: ThONALMUS-LIKe BeEtles

Callopisma adjuncta E. Oliv. (Lampyridæ) : Darlington states that it is a forest dweller, but one specimen was found in open country on the same tree with Thonalmus. Since no more were seen, it was not used experimentally. This Callopisma is about the same size as a small Thonalmus; the pronotum and anterior fifth of elytra are orange and the rest of the elytra are black. Two specimens of a yellow and black Lampyrid (Photinus nefarius E. Oliv.), of similar size, were readily eaten by an Anolis sagrei.

Drapetes bicolor Cast. (Throscidæ) : This beetle was not mentioned by Darlington. It was found in company with Thonalmus but is only $4.2 \mathrm{~mm}$. long, whereas the length of the smallest Thonalmus is $6 \mathrm{~mm}$. The head and pronotum are reddish orange and the elytra are metallic blue-green. Unfortunately Drapetes quickly died in captivity. Of six examples placed with three separate Anolis sagrei, all died within 24 hours, but only one of them was eaten.

Chalepus sanguinicollis Linn. (Hispidæ): Although not mentioned by Darlington, sanguinicollis occurred in company with Thonalmus. It is larger than the smallest Thonalmus and with orange or red on the pronotum and anterior third of elytra, extending posteriorly along the lateral margins. The head and remainder of the elytra are black. One specimen, placed with Anolis sagrei, was eaten by the following day.

Trichrous pilipennis Chev. (Cerambycidæ) : In Darlington's cage experiments an example of this species survived five days, at which time his experiment was closed. During the writer's experiments, in the course of a week, six Trichrous were placed with an Anolis sagrei, two of which were eaten the first day, another two days later; two died after being in the cage two days; and one was alive after three days in the cage. Of three Trichrous placed with another sagrei, one was eaten and one died on the second day, and the remaining example died four days later. Still another Anolis sagrei failed to eat a Trichrous during five days, when the experiment was closed. During these experiments a variety of other insects were eaten. In order to test the edibility of Trichrous, a Thonalmus, placed in the mouth 
of a sagrei, was rejected; then a Trichrous was swallowed at once. The observations indicate that although the Trichrous is edible, the Anolis has a strong tendency to avoid this Cerambycid.

A single specimen each of Anoplischius venustus (J.-D.) (Elateridæ) and Calocosmus venustus Chev. (Cerambycidæ) were taken at Soledad in June, but no more were found. Darlington collected both these species in May and illustrated them in his paper.

\section{Examples of Possible Warning Coloration}

In company with Thonalmus and therefore in the same environment as Anolis sagrei occurred several brightly colored inedible insects. The cage experiments strongly suggest that these insects are examples of warning coloration.

\section{Hemiptera Refused}

The following Hemiptera were not eaten, although Anolis readily ate plain-colored Hemiptera. Both the Dysdercus and the Oncopeltis exude a pink body fluid when handled; also Dysdercus has a characteristic odor.

Euryopthalmus sellatus (Guér.) (Pyrrhocoridæ): This species is $9-12 \mathrm{~mm}$. in length. On the upper side the pale markings are cream colored, with a narrow orange margin. The anterior, middle, and base of posterior femora are orange. The rest of the upper surface is black. Of two pairs placed with two separate Anolis sagrei, two died the following day and two were alive five days later.

Dysdercus andreæ (Linn.) (Pyrrhocoridæ): The length of this species is $8-10 \mathrm{~mm}$. The pale markings, as indicated in the photograph, are red and the rest of the upper surface black. Of two pairs placed with two separate Anolis sagrei, both were dead the next day. Darlington also found that this and the preceding species were not eaten.

Oncopeltis fasciatus (Dall.) (Lygæidæ): This species is $12 \mathrm{~mm}$. long with pale markings orange and the rest black. One example was alive after four days with an Anolis sagrei.

It seems pertinent here to quote a passage from Usinger (Univ. Calif. Publ. Ent., 7: 38, 1939). "It is interesting 
that several predaceous Hemiptera from Cuba are strikingly marked with the same brilliant red and sharply contrasting black colors as are seen in Callotriatoma. Thus Apiomerus burmeisterii Guerin and Enicocephalus cubanus Bruner are the only representatives of their respective genera (excepting other closely allied Antillean species) with such coloration. Too much of the literature on mimicry and warning coloration is made up of idle speculation based upon museum specimens, but suggestions from this source may be of value if they point out where field work may best be concentrated. If the species just named occur in the same area, it would appear that they would be mutually benefited by combining their efforts along a single line of sematic coloration."

\section{Edible Hemiptera}

In company with the inedible Hemiptera were placed several plain-colored species that were taken readily by Anolis. In addition to the following, two other unidentified bugs were quickly eaten.

Mormidea pictiventris Stal (Pentatomidæ): The length is $8 \mathrm{~mm}$., with cream colored marks on a brownish grey upper surface. Of five specimens fed to three separate Anolis sagrei, all were eaten within twenty-four hours.

Oedancala cubana Stal (Lygæidæ) : The length of cubana is $8 \mathrm{~mm}$. and the upper surface is yellow brown. One example was eaten at once.

\section{Coleoptera Refused}

Pachnæus azurescens Sch. (Curculionidæ): This $10 \mathrm{~mm}$. bluish cream weevil was not eaten after six days with an Anolis sagrei, whereas several greyish black weevils (Lachnopus near hispidus Boh.) of the same size were taken readily.

Oedionychis fasciata Fabr. (Chrysomelidæ): According to Mrs. Blake the specimen used is actually a new species heretofore confused with fasciata. The pronotum and transverse elytral band are orange, and the rest of the elytra are bluish-purple. This $5 \mathrm{~mm}$. beetle was not eaten after two days with an Anolis sagrei.

A striking example of what is apparently warning colora- 
tion is shown in the case of the Chrysomelid Cryptocephalus viridipennis Suffr., a shining metallic blue-green beetle with dark reddish brown pronotum and transverse band on elytra. Of three specimens placed with three separate Anolis sag$r e i$, one was not eaten after six days, another after five days, but one was taken after four days. Whereas Anolis ate more or less quickly three closely related species: Cryptocephalus 5-punctatus Suffr. yellow with black spots, $C$. commutatus Suffr. reddish brown to metallic blue with yellow marks, and Pachybrachys parallelopedus Suffr. with brown and yellow markings.

Three species of brightly colored Coccinellidæ, Chilocorus cacti (L.) Cycloneda sanguinea (L.) and a third unnamed, were refused by Anolis sagrei.

\section{Edible Coleoptera}

With the bright colored inedible beetles were put sombre beetles that Anolis usually ate without hesitation. Two such beetles were the Elaterids Conoderus bifoveatus (Beauv.) and Aeolus sp. Darlington mentions others that he used. Also an occasional house fly and a cockroach nymph was greedily snapped up by the lizards.

\section{Discussion}

Darlington found, in his feeding experiments with Thonalmus, that his results were absolute and surmised that they might prove to be statistical instead. That they may be statistical is shown by the present writer, especially in the case of Trichrous.

Another implication brought out by the experiments is that the feeding habits vary with the individual, probably as a result of the experience of each lizard.

An interesting aspect of the experiments is the variation in the markings of insects which are refused for no apparent reason other than mimicry or warning coloration. In some cases, as Chalepus and Drapetes, the mimicry is not close. Or a beetle, such as Oedionychis, may have the models' colors in a very different pattern. One beetle, Cryptocephalus viridipennis, has only one of the models' colors. Also the colors of Thonalmus and the inedible Hemiptera are similar. So 
Anolis seems to refuse all bright red and blue and red and black insects. If this should turn out to be true, then there would be a mutual Müllerian reinforcement of mimicry by warning coloration.

Professor Brues' photographs show that the pattern appears in ultra violet light in only one instance but is more or less present in the longer wave-lengths emitted by fluorescense. $^{2}$ Apparently the visible spectrum must be approximately the same for Anolis and man. Certainly, the testing of the visible spectrum of Anolis would be a pertinent study.

\section{EXPLANATION OF PLATE I.}

Figs. 1-33. Insects used in mimicry and warning coloration experiments. Unless stated otherwise, the photographs were taken by white light. 1 , Oncopeltis fasciatus; 2 , by fluorescent lights ; 3 , by ultra violet. 4, Euryophthalmus sellatus; 5, by fluorescent light; 6 , by ultra violet. 7 , Mormidea pictiventris; 8 , by fluorescent light; 9 , by ultra violet. 10 , Dysdercus andreae; 11, by fluorescent light; 12, by ultra violet. 13, Calocosmus venustus; 14, by fluorescent light; 15, by ultra violet. 16, Cryptocephalus viridipennis. 17, Cryptocephalus commutatus. 18, Cryptocephalus 5-punctatus. 19, Pachybrachys parallelopedus. 20, Drapetes bicolor. 21, Thonalmus aulicus (small specimen) ; 22, by fluorescent light; 23, by ultra violet. 24, Oedionychis n.sp. (near fasciata). 25, Pachnaeus azurescens. 26, Lachnopus near hispidus. 27, Trichrous divisus Chev.; 28, by fluorescent light; 29 , by ultra violet. 30, Trichrous pilipennis. 31, Callopisma adjuncta. 32, Anoplischius venustus. 33, Chalepus sanguinicollis.

\footnotetext{
${ }^{2}$ The photographs were made with a mercury vapor source with quartz condensing lens. To register reflected ultra-violet light a dark purple filter excluding wave lengths longer than 4000 angs. was interposed between the source of light and object. To register fluorescence, an additional filter excluding lengths below 4000 angs. was added, between the object and the camera lens. Photographing by white light was done with tungsten filament flood-lights, without filter, on a panchromatic emulsion.
} 

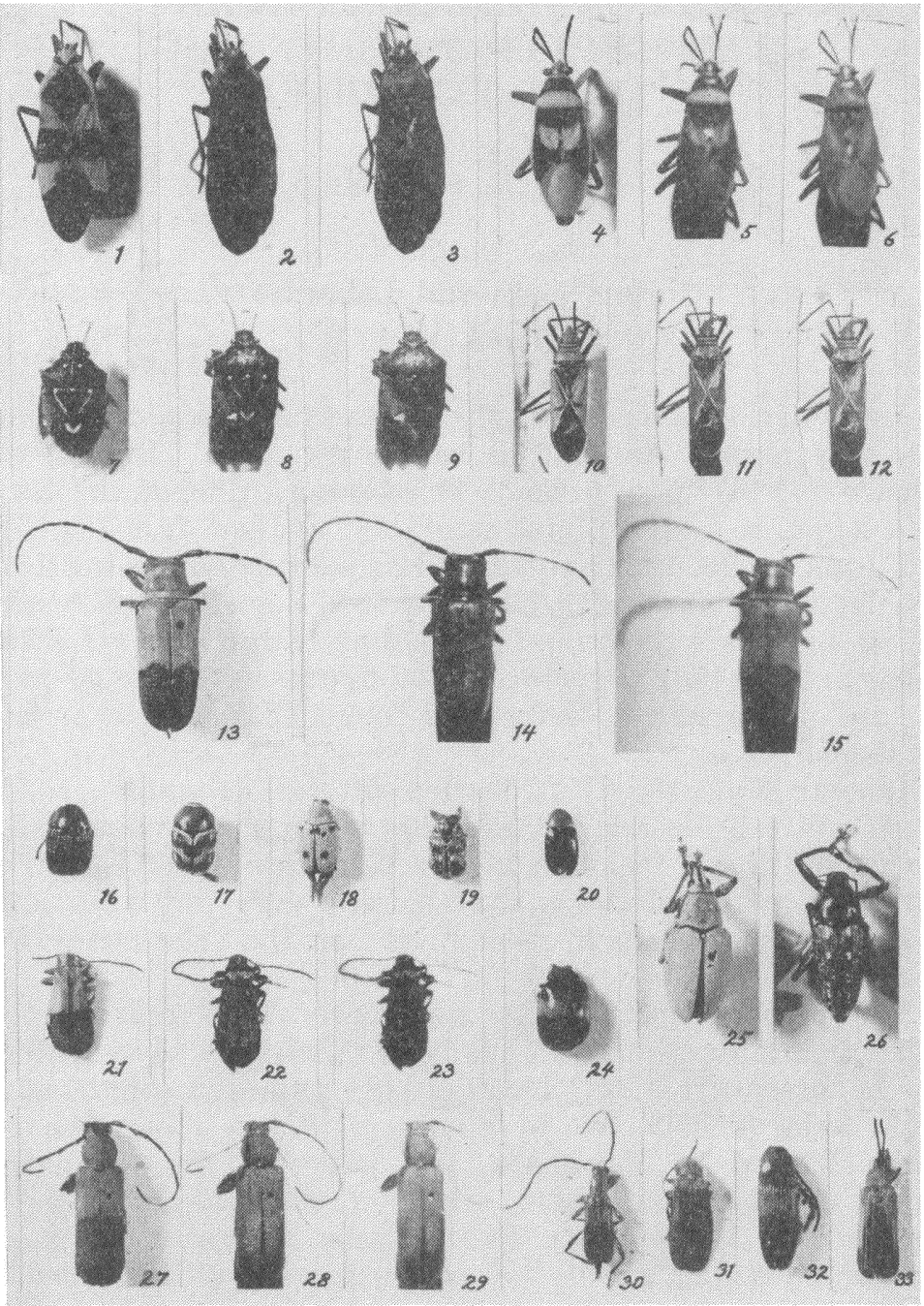

Parsons - Insect Mimicry 

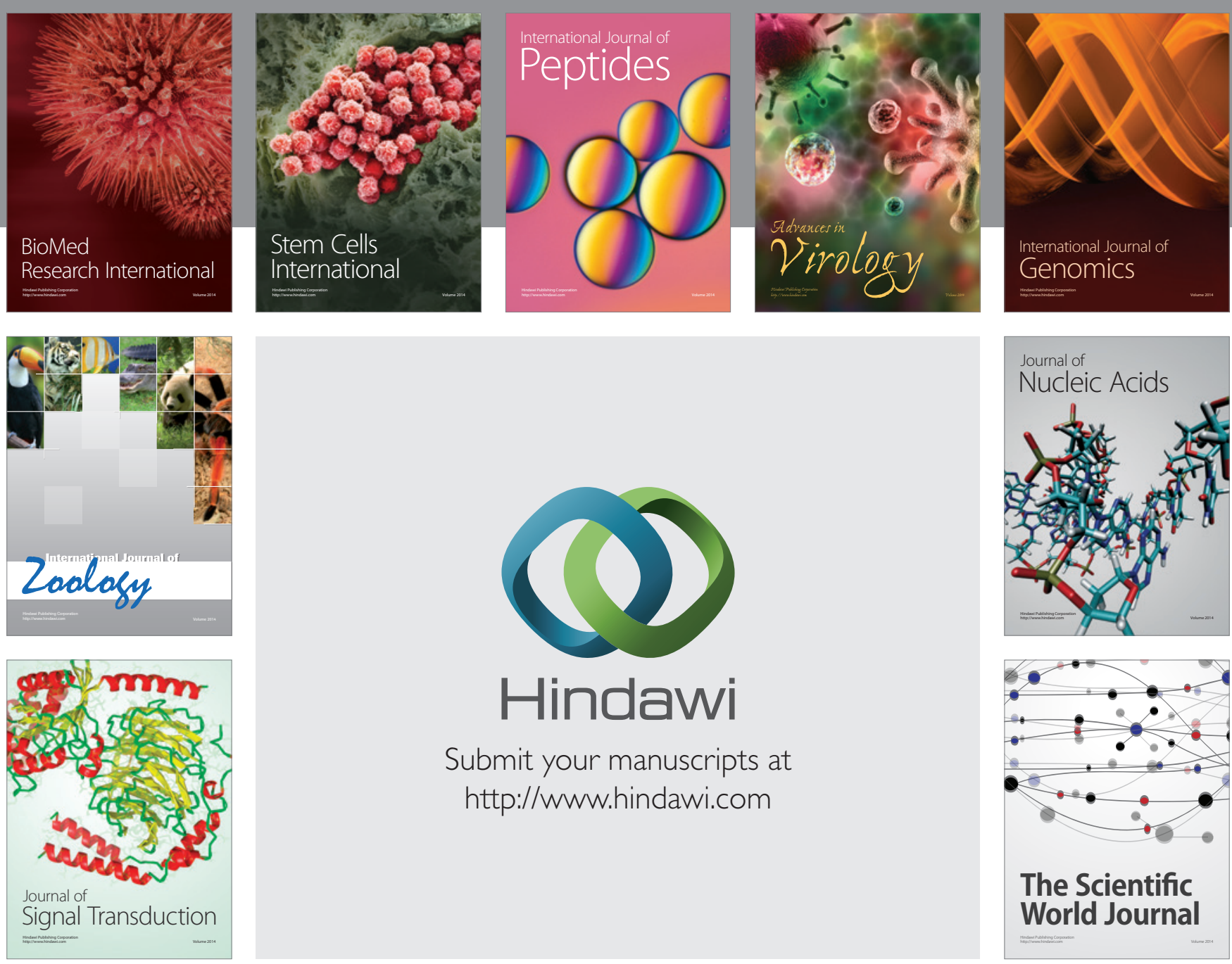

Submit your manuscripts at

http://www.hindawi.com
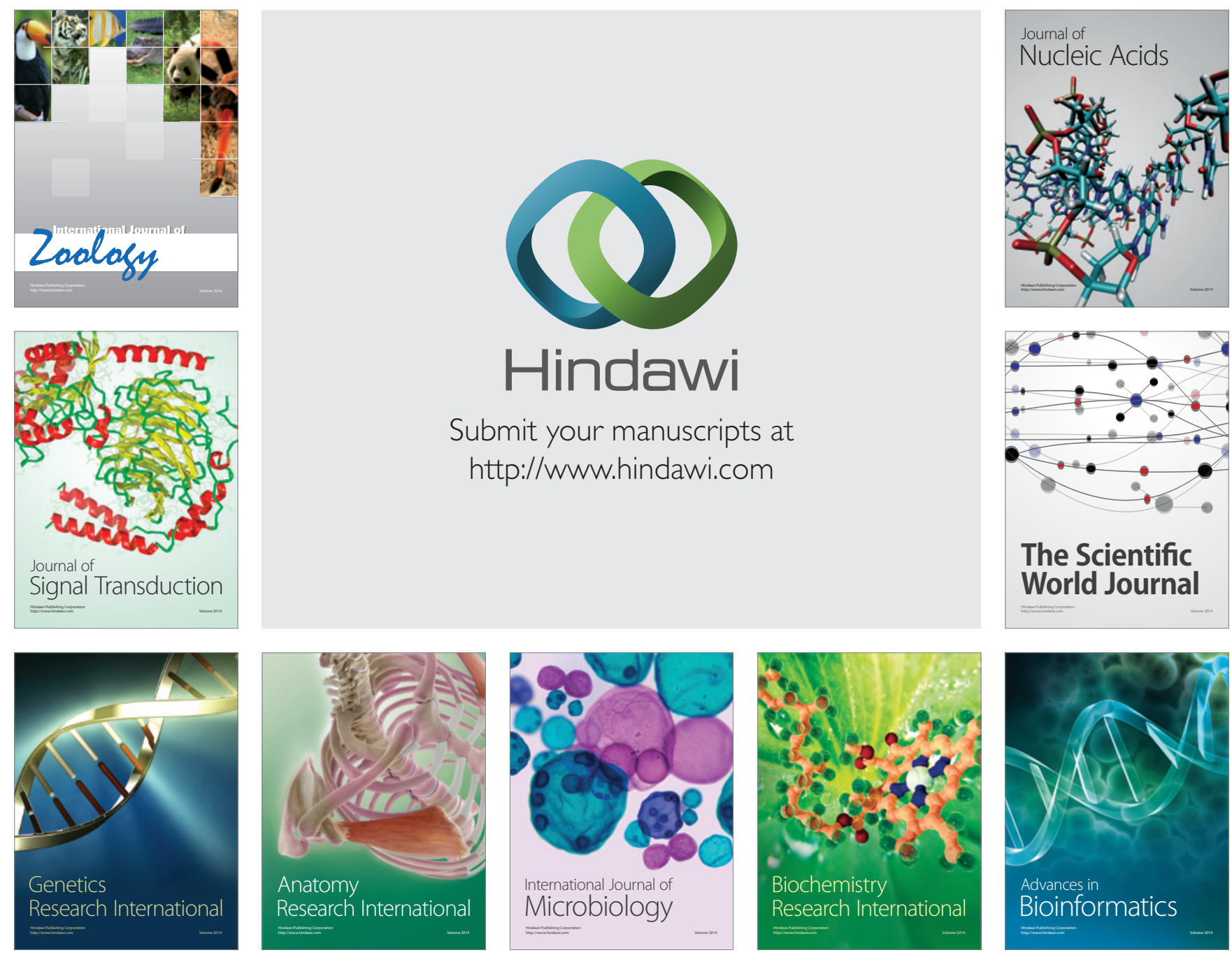

The Scientific World Journal
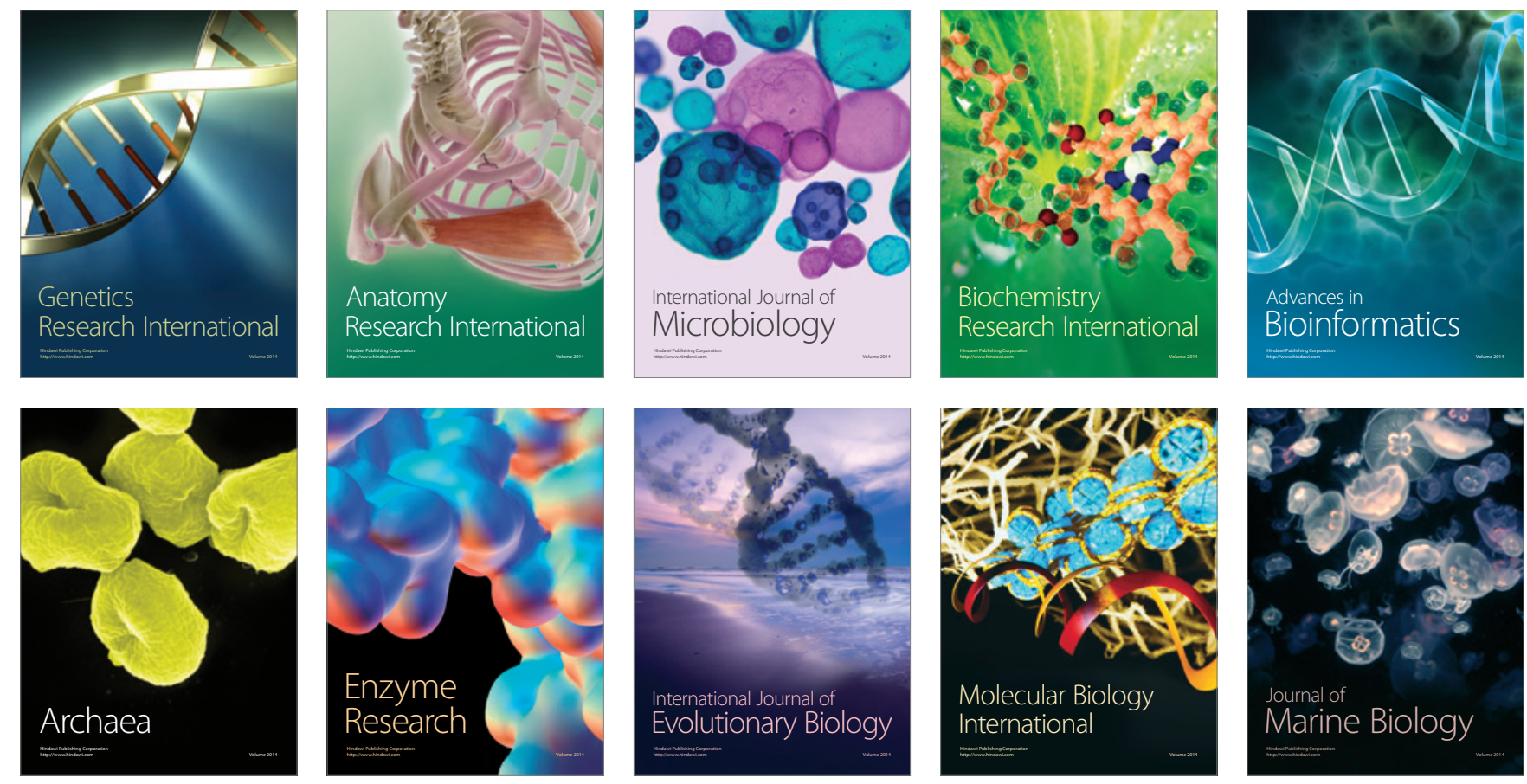